\title{
Expression of GDNF Family Receptor Components during Development: Implications in the Mechanisms of Interaction
}

\author{
Tian Yu, ${ }^{1}$ Sheila Scully, ${ }^{2}$ Yanbin Yu, Gary M. Fox, ${ }^{2}$ Shuqian $\mathrm{Jing}^{2}$ and Renping Zhou ${ }^{1}$ \\ 1 Laboratory for Cancer Research, Department of Chemical Biology, College of Pharmacy, Rutgers University, Piscataway, \\ New Jersey 08855, and 2Amgen Incorporated, Amgen Center, Thousand Oaks, California 91320-1789
}

Glial cell line-derived neurotrophic factor (GDNF) and a related factor, neurturin, promote survival of diverse groups of neurons. Both GDNF and neurturin signal via a two-component receptor complex that consists of a ligand-binding GDNF family receptor (GFR $\alpha-1$ or GFR $\alpha-2$ ) and the receptor protein tyrosine kinase Ret. Recently, a third receptor related to GFR $\alpha-1$ and GFR $\alpha-2$ has also been isolated and designated GFR $\alpha-3$. Although much is known about the interaction among GDNF family factors, Ret, and the $\alpha$-receptors in vitro, it remains unclear about their interactions in vivo. We show here by in situ hybridization that Ret and the $\alpha$-receptors may be colocalized in the same tissues or expressed separately in projecting and target tissues, respectively, indicating that two distinct modes of interaction between Ret and the $\alpha$-receptors exist in vivo. First, Ret may interact with the $\alpha$-receptors expressed in the same cells

Glial cell line-derived neurotrophic factor (GDNF) is a potent survival factor for many central and peripheral neurons, including midbrain dopaminergic neurons (Lin et al., 1993; Beck et al., 1995; Tomac et al., 1995), spinal cord motoneurons (Henderson et al., 1994; Li et al., 1995), cerebellar Purkinje cells (Mount et al., 1995), and sensory and autonomic neurons (Buj-Bello et al., 1995). In addition, GDNF is essential for the development of the kidney and enteric nervous system (Moore et al., 1996; Pichel et al., 1996; Sanchez et al., 1996). Recently, a novel GDNF-related neurotrophic factor, neurturin, has been isolated (Kotzbauer et al., 1996) and shown to have similar activities to GDNF. For example, both molecules promote the survival of sympathetic neurons of the superior cervical ganglia and sensory neurons of the nodose and dorsal root ganglia (Henderson et al., 1994; Buj-Bello et al., 1995; Ebendal et al., 1995; Oppenheim et al., 1995; Trupp et al., 1995; Yan et al., 1995; Kotzbauer et al., 1996).

The biological action of GDNF is mediated by a two-component receptor complex consisting of a glycosylphosphatidylinositollinked cell surface molecule, the GDNF family receptor GFR $\alpha-1$ (originally named GDNFR- $\alpha$ ), and the receptor protein tyrosine kinase Ret (Durbec et al., 1996b; Jing et al., 1996; Treanor et al.,

Received Feb. 17, 1998; accepted March 31, 1998.

This research is funded in part by National Science Foundation Grant IBN9409930, NIH Grant IROINS 36788-01, and by a grant from the Alzheimer's Foundation. We acknowledge M. Fang, Z. Hu, and M. Qi for construction of the probes used in in situ hybridization experiments and G. W. Mcauliffe and D. Crockett for insightful help in histology.

T.Y. and S.S. contributed equally to this work.

Correspondence should be addressed to Dr. Renping Zhou, Laboratory for Cancer Research, Department of Chemical Biology, College of Pharmacy, Rutgers University, Piscataway, NJ 08855 or Dr. Shuqian Jing, Amgen Inc., Amgen Center, Thousand Oaks, CA 91320-1789.

Copyright (C) 1998 Society for Neuroscience $\quad 0270-6474 / 98 / 184684-13 \$ 05.00 / 0$ (termed interaction "in cis") in many tissues and cell populations that respond to GDNF and/or neurturin, such as the substantia nigra, dorsal root ganglia, spinal cord motoneurons, kidney, and intestine. Second, Ret may interact with the $\alpha$-receptors localized in the target neurons (termed interaction "in trans"). In addition, we present evidence in vitro that GFR $\alpha-1$ mediates Ret activation by GDNF in trans. These observations suggest that there are multiple mechanisms regulating the interaction between Ret and the $\alpha$-receptors that mediates the effects of GDNF family trophic factors on the survival and differentiation of cells and on neuron-target interactions in the nervous system.

Key words: neurotrophic factors; Ret tyrosine kinase; GDNF family receptors; neurturin; neuron-target interaction; in situ hybridization
1996; Trupp et al., 1996). In the absence of GFR $\alpha-1$, GDNF fails to bind and activate Ret in vitro (Jing et al., 1996; Treanor et al., 1996). Mice bearing null mutations of Ret exhibit similar phenotypic defects to that of GDNF knock-out animals, including renal agenesis or severe dysgenesis and lack of enteric neurons, indicating that Ret is a key component involved in GDNF signaling in vivo (Edery et al., 1994; Romeo et al., 1994; Schuchardt et al., 1994; Sanchez et al., 1996).

Two GFR $\alpha$-1-related molecules, GFR $\alpha-2$ and GFR $\alpha-3$, have been isolated recently (Baloh et al., 1997; Buj-Bello et al., 1997; Jing et al., 1997; Klein et al., 1997; Sanicola et al., 1997). Receptor-binding, cross-linking, and receptor activation studies have shown that GFR $\alpha-2$ is a binding receptor for both neurturin and GDNF and mediates phosphorylation of the Ret tyrosine kinase. However, GFR $\alpha$-2 exhibits a marked preference for interaction with neurturin (Baloh et al., 1997; Jing et al., 1997). Similarly, neurturin has been shown to bind and activate Ret via GFR $\alpha-1$, although much less efficiently than GDNF (Baloh et al., 1997; Jing et al., 1997). Even though the ligand for GFR $\alpha-3$ remains unknown, the amino acid sequence and structural homology of this receptor to GFR $\alpha-1$ and GFR $\alpha-2$ suggest that it is likely to signal via Ret receptor protein tyrosine kinase as well (Jing at al., 1997).

Ret tyrosine kinase is activated efficiently by GDNF or neurturin when the $\alpha$-receptors are coexpressed with Ret in the same cells (Jing et al., 1996, 1997), indicating a functional "cis" interaction. Here we provide evidence from in vivo expression and in vitro tyrosine kinase activation that the $\alpha$-receptors may also mediate Ret activation by GDNF or neurturin "in trans," suggesting a role in regulating neuron-target interactions. 

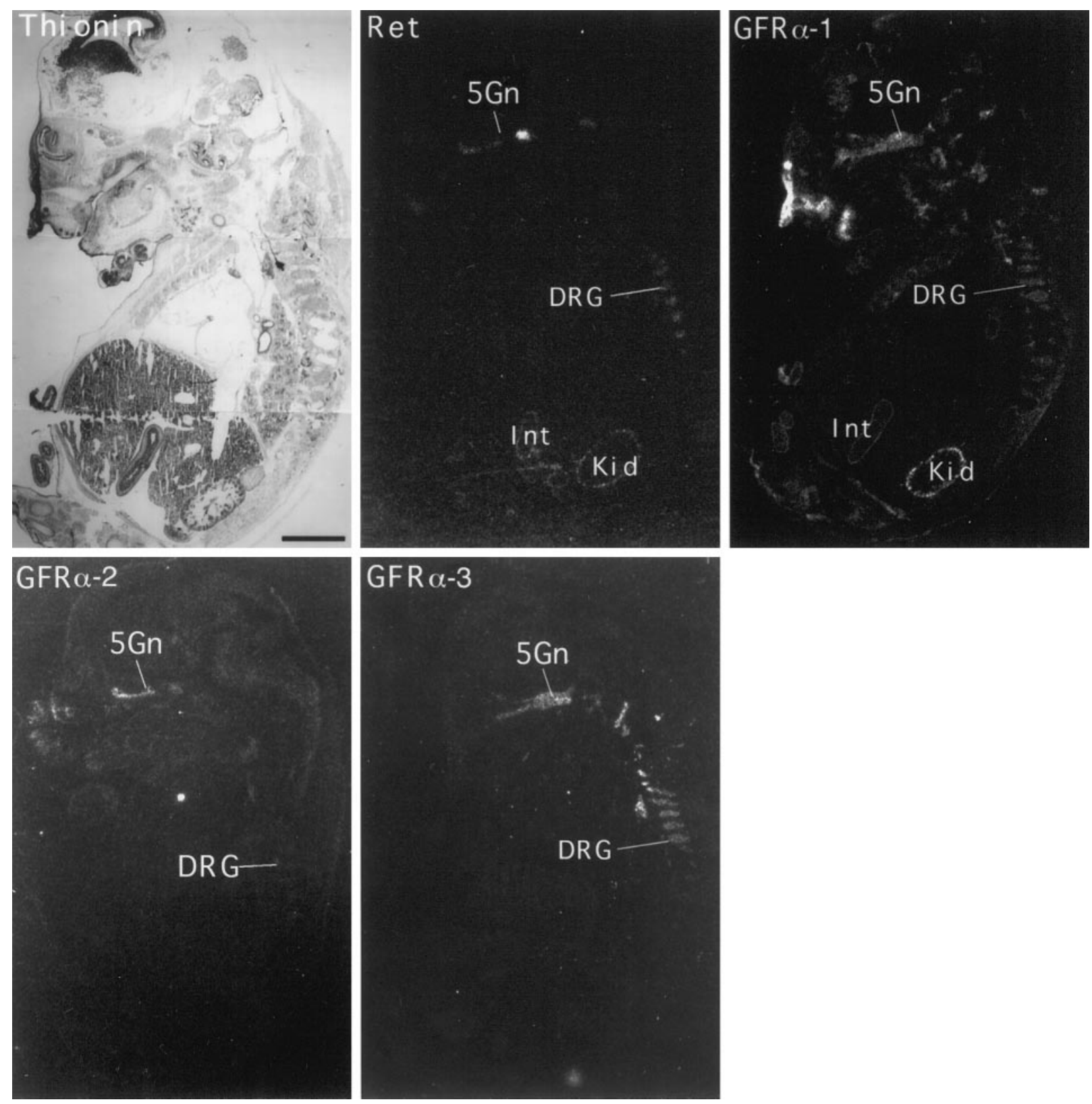

Figure 1. Expression of Ret, GFR $\alpha$-1, GFR $\alpha$-2, and GFR $\alpha-3$ in E18 rat embryos. Serial parasagittal sections were hybridized to antisense riboprobes of Ret, GFR $\alpha-1$, GFR $\alpha-2$, and GFR $\alpha-3$, respectively. The first panel of this and the following figures is a bright-field picture of a serial section counterstained with thionin or eosin. The other panels are dark-field pictures of sections hybridized with the indicated probes. Sense probes of the receptors revealed no specific hybridization patterns. $D R G$, Dorsal root ganglia; Int, intestine; Kid, kidney; $5 \mathrm{Gn}$, trigeminal ganglia. Scale bar, $1.75 \mathrm{~mm}$.

\section{MATERIALS AND METHODS}

Animals. Embryonic day 18 (E18) fetuses, postnatal day 7 (P7) pups, and the adults of Sprague Dawley rats were used in this study. The occurrence of a vaginal plug was defined as E1, and the day of birth was P1. At least three rats at each age were analyzed. Embryos and brains were dissected under carbon dioxide anesthesia and immediately frozen on powdered dry ice. Coronal and sagittal sections of $14 \mu \mathrm{m}$ thickness were cut on a cryostat at $-20^{\circ} \mathrm{C}$ and thaw-mounted onto glass slides. Before the experiments, the slides had been delipidated with acetone, followed by $100 \% \mathrm{EtOH}$ (5 min each), and then dipped in 2\% triethoxy-3aminopropyl silane (Sigma, St. Louis, MO) for $5 \mathrm{~min}$. The treated slides were washed first with acetone and then with $\mathrm{H}_{2} \mathrm{O}$ for 5 min each. Slide-mounted sections were then stored at $-80^{\circ} \mathrm{C}$ until use (up to 2 months).

Probes. For detection of GDNF family receptor expression using in situ hybridization, ${ }^{35} \mathrm{~S}$ - or ${ }^{33} \mathrm{P}$-labeled riboprobes were generated from vari- ous plasmids containing the receptors (see the following descriptions) using either T7 or SP6 RNA polymerases. The Ret probe is a 262 nucleotide (nt) fragment of a rat Ret cDNA that encodes amino acids 105-192 of the extracellular domain (Iwamoto et al., 1993; Jing et al., 1996). GFR $\alpha$-1 transcripts were detected with two different probes derived from the rat receptor cDNA. The first, GR400, is a $393 \mathrm{nt}$ riboprobe (corresponding to amino acid positions 126-256 of GFR $\alpha-1$ ) (Jing et al., 1996). GR400 has a homology of 74.3 and $58.8 \%$ with the corresponding regions in GFR $\alpha-2$ and GFR $\alpha-3$, respectively, in the nucleotide level. The second, GR396, is $396 \mathrm{bp}$ and corresponds to amino acid positions 258-389 of GFR $\alpha$ - 1 (Jing et al., 1996). The GR396 sequence shares a homology of $59.8 \%$ with GFR $\alpha-2$ and $56.3 \%$ with GFR $\alpha-3$ in the corresponding regions in the nucleotide level. The patterns of GFR $\alpha-1$ expression revealed by both probes are identical. Data presented in this report are only from experiments with the GR396 probe. GFR $\alpha-2$ mRNA was also detected with two different probes, RGL240 and 

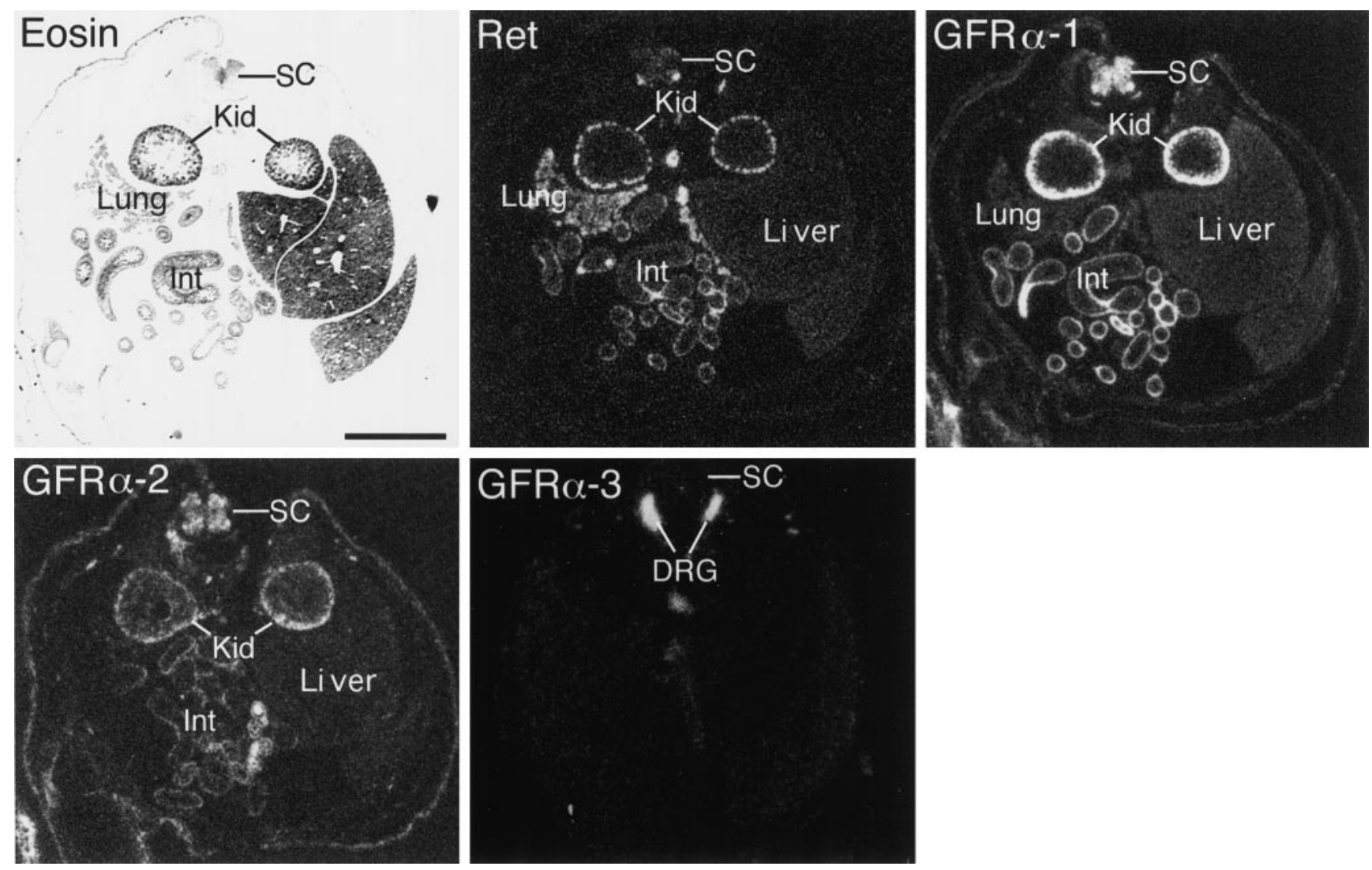

Figure 2. Expression of Ret, GFR $\alpha-1$, GFR $\alpha$-2, and GFR $\alpha-3$ in E18 rat kidney and intestine. Serial cross-sections through the kidney and intestine of E18 rat embryos were hybridized to antisense riboprobes of the four receptors. DRG, Dorsal root ganglia; Int, intestine; Kid, kidney; SC, spinal cord. Scale bar, $1.65 \mathrm{~mm}$.

RGL205. RGL240 is a 249 nt riboprobe corresponding to amino acid positions $107-189$ of rat GFR $\alpha-2$ and shares 70 and $57.0 \%$ nucleotide sequence homology with rat GFR $\alpha-1$ and GFR $\alpha-3$ in the corresponding regions, respectively (Jing et al., 1997). RGL205 is 205 bp and derived from amino acid positions $262-330$ of the rat GFR $\alpha-2(68.8$ and $49.3 \%$ nucleotide sequence homology with GFR $\alpha-1$ and GFR $\alpha-3$ in the corresponding regions, respectively) (Jing et al., 1997). Both probes revealed the same expression pattern of GFR $\alpha$-2, but only data obtained with RGL205 are presented in this report. GFR $\alpha-3$ transcripts were hybridized with a $225 \mathrm{nt}$ riboprobe, pMFR3, corresponding to amino acid positions $225-300$ of the rat GFR $\alpha-3$ (71.1 and 57.0\% nucleotide homology with GFR $\alpha-1$ and GFR $\alpha-2$ in the corresponding regions, respec- tively) (Jing et al., 1997). The $\alpha$-receptor probes are specific for each transcript, and no cross-hybridization has been observed either in our previous Northern blot analyses (Jing et al., 1997) or in in situ hybridization experiments in current studies. Sense probes corresponding to the same regions as the antisense probes were used in parallel experiments for controls. All antisense and sense probes were synthesized by in vitro transcription with $\left[{ }^{35} \mathrm{~S}\right]-$ or $\left[{ }^{33} \mathrm{P}\right] \mathrm{UTP}$ (New England Nuclear).

In situ hybridization. In situ hybridization was performed as described previously (Zhang et al., 1997). Briefly, slide-mounted sections were warmed quickly to room temperature and fixed in $4 \%$ paraformaldehyde in $0.1 \mathrm{M}$ phosphate buffer, $\mathrm{pH} 7.2$ (all treatments were performed at room temperature unless otherwise indicated). The sections were further
Figure 3. Expression of Ret, GFR $\alpha-1$, and GFR $\alpha-2$ in E18 rat kidney. Serial cross-sections of E18 rat embryos through the kidney were hybridized to the three receptor riboprobes as described in detail in Materials and Methods. Note that Ret and GFR $\alpha-1$ were coexpressed in ureteric buds, whereas GFR $\alpha$ - 2 was detected in the mesenchymal tissues surrounding both the ureteric buds and the maturing nephrons. Scale bar, $0.25 \mathrm{~mm}$.
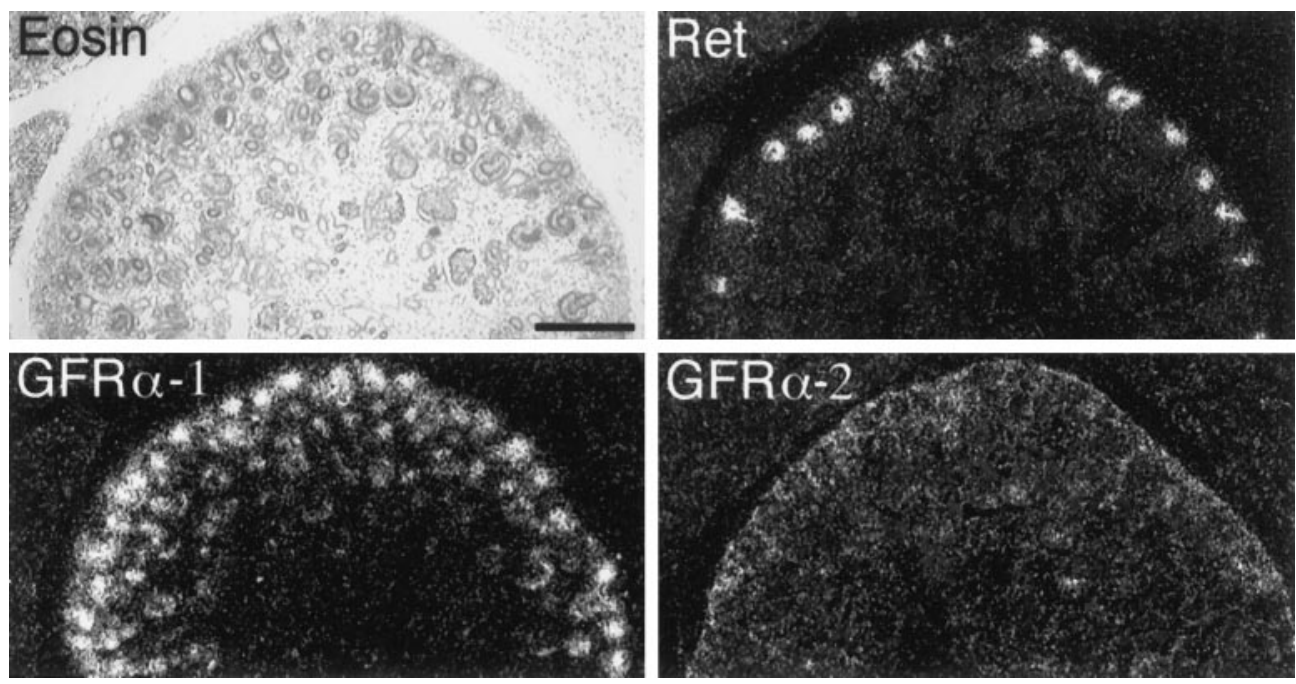


\begin{tabular}{|c|c|c|c|c|}
\hline Tissues & Ret & GFR $\alpha-1$ & $\operatorname{GFR} \alpha-2$ & $\operatorname{GFR} \alpha-3$ \\
\hline \multicolumn{5}{|l|}{ Non-neural } \\
\hline Kidney & +++ & +++ & +++ & - \\
\hline Intestine & +++ & +++ & +++ & - \\
\hline Lung & ++ & + & \pm & - \\
\hline \multicolumn{5}{|l|}{ PNS } \\
\hline Retina & +++ & +++ & + & - \\
\hline Trigeminal ganglia & +++ & +++ & ++ & +++ \\
\hline Superior cervical ganglia & +++ & +++ & ++ & +++ \\
\hline Dorsal root ganglia & +++ & ++ & ++ & +++ \\
\hline \multicolumn{5}{|l|}{ Spinal cord } \\
\hline Dorsal & \pm & + & + & - \\
\hline Ventral & +++ & +++ & + & - \\
\hline \multicolumn{5}{|l|}{ Brain* } \\
\hline Hypothalamus & + & +++ & + & - \\
\hline \multicolumn{5}{|l|}{ Thalamus } \\
\hline Reticular & ++ & +++ & ++ & - \\
\hline Ventral medial & + & +++ & ++ & - \\
\hline Substantial nigra & +++ & +++ & - & - \\
\hline Zona incerta & +++ & +++ & ++ & - \\
\hline Amygdala & ++ & ++ & ++ & - \\
\hline
\end{tabular}

*Data from P7 rat brain. All other results are from E18 rat embryos.,,++++++ , \pm , and - indicate strong, moderate, weak, very weak, and no hybridization signals.

treated with proteinase $\mathrm{K}(40 \mathrm{ng} / \mathrm{ml})$ for $30 \mathrm{~min}$, refixed with $4 \%$ paraformaldehyde for $15 \mathrm{~min}$, immersed in triethanolamine $(50 \mathrm{mM})$ in acetic anhydride solutions $(100 \mathrm{~mm})$ for $10 \mathrm{~min}$, and dehydrated. The sections were hybridized with the respective riboprobe $\left(2.5 \times 10^{6} \mathrm{cpm} /\right.$ $\mathrm{ml}$ ) under stringent conditions $(50 \%$ formamide, $10 \%$ dextran sulfate, $1 \times$ Denhardt's solution, $0.2 \mathrm{mg} / \mathrm{ml}$ Herring sperm DNA, and $10 \mathrm{~mm}$ dithiothreitol) for $18-24 \mathrm{hr}$ at $55^{\circ} \mathrm{C}$. After hybridization, the sections were washed in $5 \times \mathrm{SSC}$ at $65^{\circ} \mathrm{C}$ for $20 \mathrm{~min}$, followed by $50 \%$ formamide in $2 \times \mathrm{SSC}$ for $30 \mathrm{~min}$ at the same temperature. The sections were washed

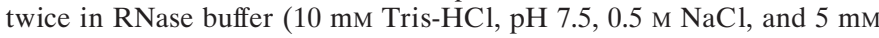
EDTA) for $20 \mathrm{~min}$ each and incubated for $30 \mathrm{~min}$ at $37^{\circ} \mathrm{C}$ in the same buffer containing $20 \mu \mathrm{g} / \mathrm{ml}$ RNase A. Sections were rinsed in the RNase buffer for $20 \mathrm{~min}$ at $37^{\circ} \mathrm{C}$. Finally, the sections were washed in $50 \%$ formamide, in $2 \times \mathrm{SSC}$ at $65^{\circ} \mathrm{C}$ for $30 \mathrm{~min}$, in $2 \times \mathrm{SSC}$ and in $0.1 \times \mathrm{SSC}$ at room temperature for $15 \mathrm{~min}$ each. After washes, the sections were dehydrated and exposed to x-ray film for 3-6 d. After film development, the sections were coated with Kodak NTB-2 photographic emulsion, diluted 1:1 with distilled water. The sections were exposed for 2-3 weeks at $4^{\circ} \mathrm{C}$, developed, and counterstained with thionin or eosin.

The expression analysis of each gene was done on at least three different animals at the appropriate age. To control the potential variation in hybridization signal between experiments, we treated complete sets of serial tissue sections of E18 embryos and P7 pups simultaneously under identical conditions for each probe.

Quantitation of in situ hybridization signals. For the purpose of a general survey of the expression of GDNF family receptors in disparate regions of the rat nervous system at E18 and P7, a semiquantitative analysis was performed. The relative levels of signals in all the sections hybridized were visually inspected and assigned a grade. The strongest and background hybridization were designated " ++ +" and "-," respectively. Intermediate signal levels were given ",++ , “+," and ", $\pm "$ depending on the relative intensity compared with the strongest and weakest signals. Complete quantitative analysis was not done because of difficulties created by signal variations within a particular structure (i.e., septum) or cell type (i.e., hippocampal pyramidal cells).

Ret tyrosine kinase activation assay. The effect of GFR $\alpha-1$ provided in trans on Ret tyrosine kinase activation was assayed with both soluble recombinant human GFR $\alpha-1$ protein fused to the human $\operatorname{IgG~Fc~domain~}$ $(\mathrm{GFR} \alpha-1 / \mathrm{Fc})$ or $\mathrm{GFR} \alpha-1 / \mathrm{Fc}$ immobilized on protein A-Sepharose beads. For assay with soluble GFR $\alpha-1 / \mathrm{Fc}$, conditioned medium (CM) of a $293 \mathrm{~T}$ cell line secreting the receptor-Fc fusion protein, constructed
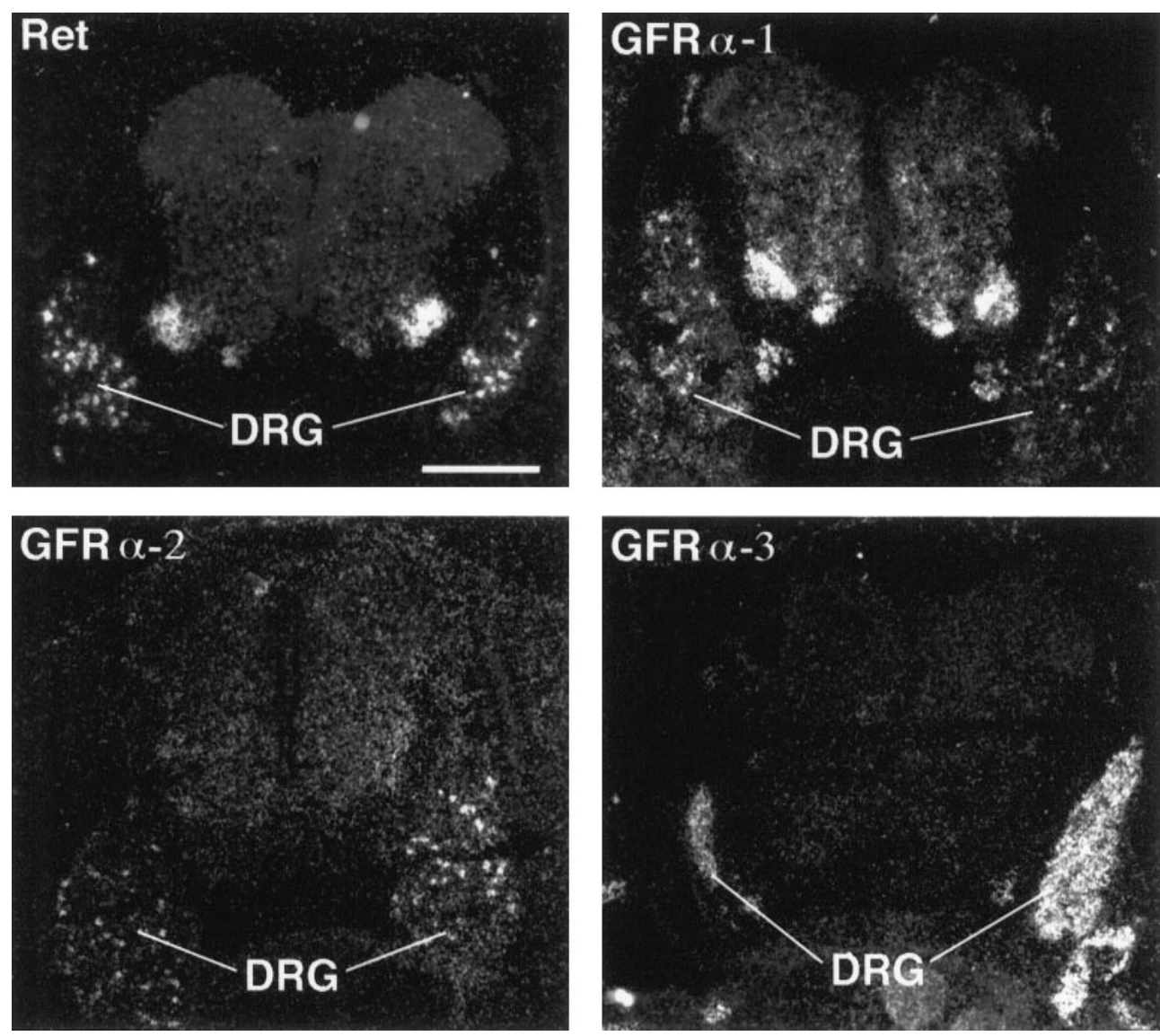

Figure 4. Expression of Ret, GFR $\alpha-1$, GFR $\alpha-2$, and GFR $\alpha-3$ in E18 rat spinal cord. Serial cross-sections of E18 rat embryos through the spinal cord were hybridized with riboprobes against the four receptors, respectively. Control sense probe did not show any specific patterns of hybridization signal (data not shown). $D R G$, Dorsal root ganglia. Scale bar, 0.6 $\mathrm{mm}$. 

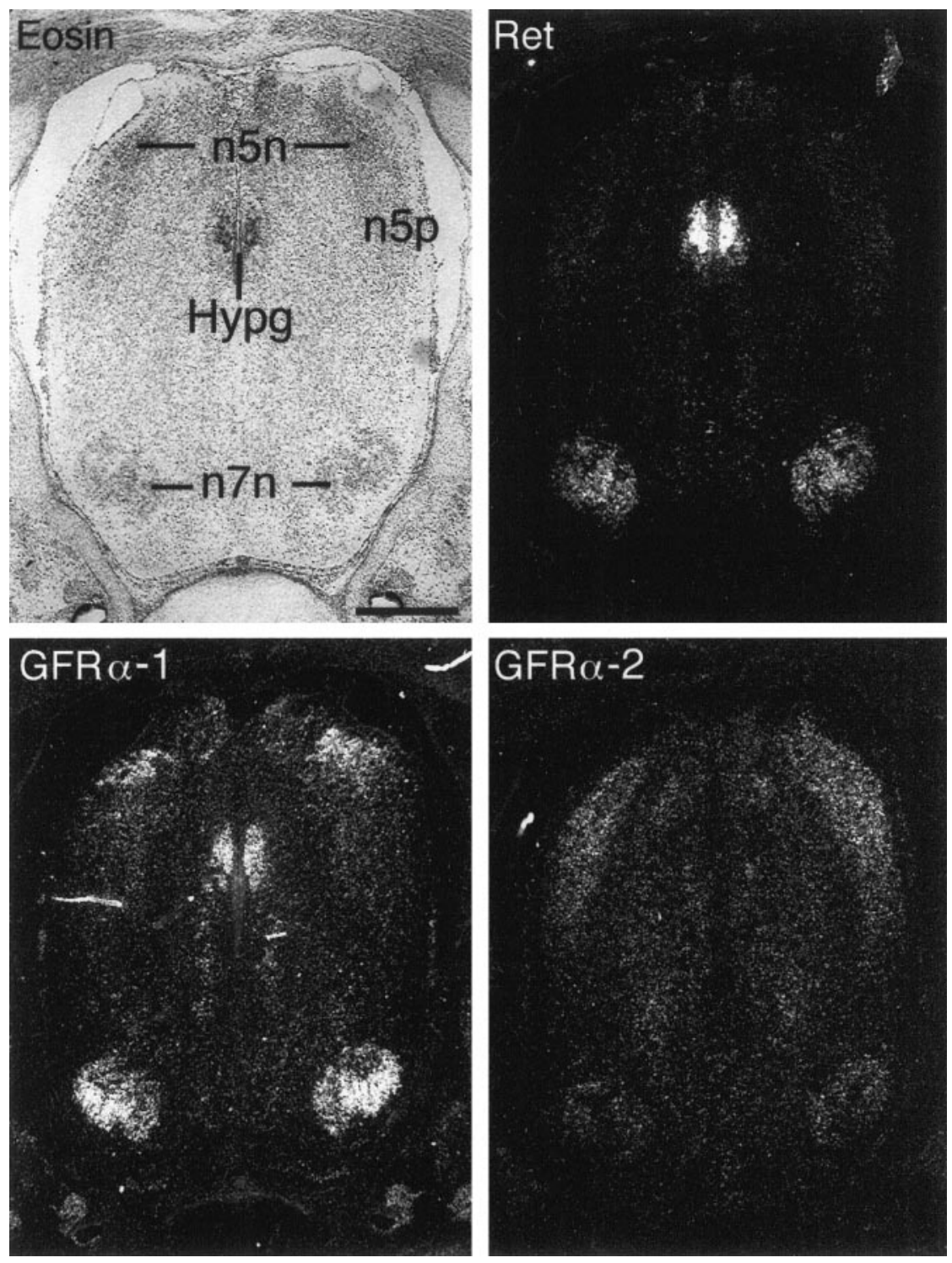

Figure 5. Expression of Ret, GFR $\alpha-1$, and GFR $\alpha$-2 in the brainstem. Serial horizontal sections of E18 embryonic head were hybridized to the antisense probes of Ret, GFR $\alpha-1$, and GFR $\alpha-2$, respectively. Hybridization with sense probes for these receptors showed no specific hybridization patterns (data not shown). Hypg, Hypoglossal nucleus; $n 5 n$, the principle (motor) trigeminal nucleus; $n 5 p$, the principle (sensory) trigeminal nucleus; $n 7 n$, facial motor nuclei. Scale bar, $0.5 \mathrm{~mm}$.

the same amount of GFR $\alpha-1 / \mathrm{Fc}$ alone, buffer with both GDNF and protein A-Sepharose beads, or buffer with $\mathrm{GFR} \alpha-1 / \mathrm{Fc} /$ protein A-Sepharose bead complexes. Treated Neuro-2a cells were then lysed, and the cell lysates were immunoprecipitated using an anti-Ret antibody. The immunoprecipitates were fractionated by SDS-PAGE and blotted using an antiphosphotyrosine antibody as described previously (Jing et al., 1996). the GDNF and CM mixture and further incubated at room tempe or 30 min. The GDNF/GFR $\alpha-1 / \mathrm{Fc} /$ protein A-Sepharose complex collected by centrifugation in a microcentrifuge at 14,000 rpm for $5 \mathrm{~min}$, washed three times with $1 \mathrm{ml}$ of binding buffer (DMEM containing 2 $\mathrm{mg} / \mathrm{ml}$ bovine serum albumin and $25 \mathrm{mM}$ HEPES, $\mathrm{pH}$ 7.0) prewarmed to $37^{\circ} \mathrm{C}$, and resuspended to $1 \mathrm{ml}$ of binding buffer for Ret activation assay. To examine the stability of the complex, we incubated $50 \mu \mathrm{l}$ aliquots of $\mathrm{GDNF} / \mathrm{GFR} \alpha-1 / \mathrm{Fc} /$ protein A-Sepharose beads in binding buffer at $37^{\circ} \mathrm{C}$ for various periods of time $(0-10 \mathrm{~min})$. The beads were separated from the liquid phase by filtration through $0.45 \mu \mathrm{m}$ filters. Filtered solutions were then analyzed by SDS-PAGE along with an equivalent amount of $\mathrm{CM}(50 \mu \mathrm{l})$. The gel was transferred to a nitrocellulose filter, and the amount of the GFR $\alpha-1 / \mathrm{Fc}$ protein dissociated from protein A beads during incubation was determined by Western blot analysis using horseradish peroxidase-conjugated protein $\mathrm{A}$.

To test the ability of GFR $\alpha-1$ to activate Ret receptor protein tyrosine kinase in trans, we seeded Neuro-2a cells, which express high levels of Ret, in six-well cluster tissue culture dishes at a density of $1.5 \times 10^{6}$ cells/well $24 \mathrm{hr}$ before Ret activation. Cells were then treated with CM containing soluble GFR $\alpha-1$-Fc or with protein A-Sepharose-immobilized $\mathrm{GDNF} / \mathrm{GFR} \alpha-1 / \mathrm{Fc}$ complexes at $37^{\circ} \mathrm{C}$ for $5 \mathrm{~min}$. For negative controls, parallel cultures were treated with $1 \mathrm{ml}$ of binding buffer, buffer with protein A-Sepharose only, buffer with $50 \mathrm{~nm}$ GDNF alone, buffer with

\section{RESULTS}

\section{Colocalization of Ret and GDNF family $\alpha$-receptors in the developing rat}

To examine the potential mechanisms of interaction between Ret and the $\alpha$-receptors in vivo, we compared expression of these molecules during rodent development. Embryonic (E18) and postnatal (P7) rats were examined in detail by in situ hybridization using antisense riboprobes specific to each of the receptors. These studies showed that Ret was coexpressed with at least one of the $\alpha$-receptors in many different types of cells known to be responsive to GDNF or neurturin.

\section{Non-neural tissues}

High levels of expression of Ret, GFR $\alpha-1$, and $\operatorname{GFR} \alpha-2$ were detected in the kidney and intestine in E18 rat embryos (Figs. 1, 

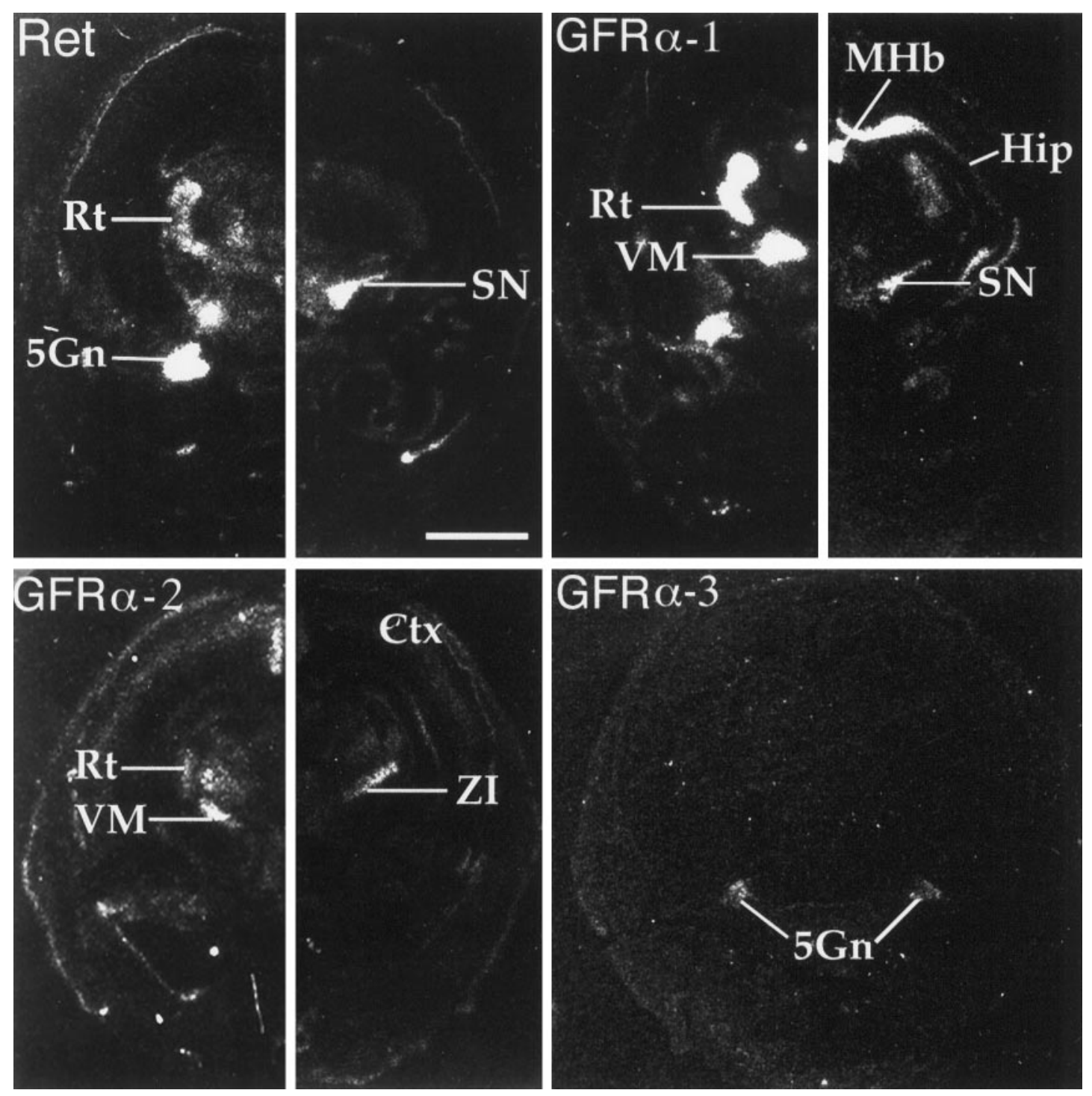

Figure 6. Expression of Ret, GFR $\alpha-1$, GFR $\alpha-2$, and GFR $\alpha-3$ in the P7 thalamus and substantia nigra. Panels for GFR $\alpha-3$ and on the left for Ret, GFR $\alpha-1$, and GFR $\alpha-2$ are coronal sections through the reticular nucleus of the thalamus, and panels on the right are coronal sections through the posterior hippocampus and substantia nigra. Ctx, Cortex; Hip, hippocampus; $M H b$, medial habenular nucleus; Rt, reticular nucleus of the thalamus; SN, substantia nigra; $V M$, ventromedial thalamic nucleus; $Z I$, zona incerta; $5 \mathrm{Gn}$, trigeminal ganglia. Scale bar, $2.4 \mathrm{~mm}$.

2, 3; Table 1). Moderate Ret, low GFR $\alpha-1$, and weak GFR $\alpha-2$ expressions were also observed in the lung (Fig. 2; Table 1). In the kidney, the expression of Ret was restricted to the ureteric buds along the edge of the tissue (Fig. 3). GFR $\alpha$-1 was also transcribed at high levels in the ureteric buds. In addition, GFR $\alpha$-1 transcripts were observed in the maturing nephrons, with decreasing levels in increasingly mature structures (Fig. 3). In contrast, GFR $\alpha-2$ was transcribed diffusely in the mesenchymal tissues surrounding the nephrons, with slightly higher levels along the edge of the kidney (Fig. 3). GFR $\alpha$-3 expression was not apparent at this stage, although at postnatal day 7, diff use signals were detected (data not shown). Thus in the kidney, Ret and GFR $\alpha-1$ were colocalized in the ureteric buds, whereas GFR $\alpha-2$ was observed in tissues surrounding the ureteric buds. The distinct localization of GFR $\alpha-1$ and GFR $\alpha-2$ suggests unique roles of these receptors in kidney morphogenesis.

\section{Neural tissues}

The coexpression of Ret and the $\alpha$-receptors was also observed in the nervous system. High levels of Ret, GFR $\alpha-1$, and GFR $\alpha-3$ and moderate levels of GFR $\alpha-2$ mRNAs were detected in E18 trigeminal ganglia (see Figs. 1, 6, 7; Table 1) and superior cervical ganglia (Table 1). Strong expression of Ret and GFR $\alpha-3$ and moderate expression of GFR $\alpha-1$ and GFR $\alpha-2$ were also observed in dorsal root ganglia (Fig 4; Table 1). In the spinal cord, high levels of Ret and GFR $\alpha-1$ expression were observed in the ventral horn where motoneuron cell bodies are located (Fig. 4). A low level signal for GFR $\alpha-1$ and GFR $\alpha-2$ was also detected in other regions of the spinal cord, whereas GFR $\alpha-3$ mRNA was absent throughout (Figs. 2, 4; Table 1). In the pons, high levels of Ret and GFR $\alpha$ - 1 were detected in the hypoglossal nucleus and facial nucleus (Fig. 5). Weak GFR $\alpha$-2 expression was also detected in these regions (Fig. 5). In addition, low levels of Ret and moderate 

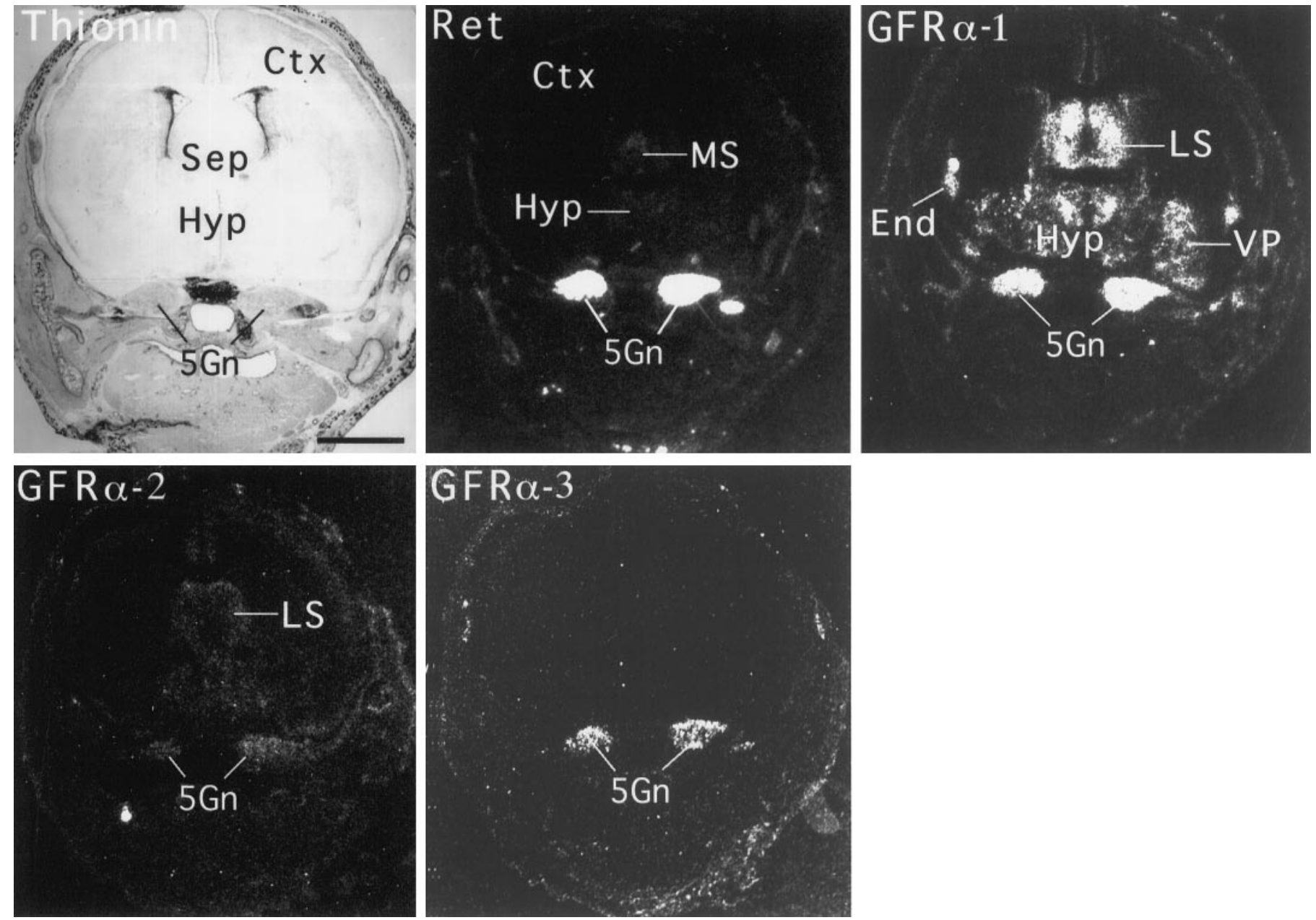

Figure 7. Expression of Ret and GFR $\alpha$ receptors in the P7 forebrain. Serial coronal sections through the forebrain were hybridized with antisense probes to Ret, GFR $\alpha-1$, GFR $\alpha-2$, and GFR $\alpha-3$, respectively. Sense probes revealed no specific hybridization signals (data not shown). Ctx, Cortex; End, endopiriform nucleus; Hyp, hypothalamus; $L S$, lateral septum; $M S$, medial septum; Sep, septum; VP, ventral pallidum; $5 G n$, trigeminal ganglia. Scale bar, $2 \mathrm{~mm}$.

levels of GFR $\alpha$-1 and GFR $\alpha$-2 were transcribed in the trigeminal nuclei (Fig. 5). In the midbrain, transcripts for both Ret and GFR $\alpha-1$, but not GFR $\alpha$-2, were detected in the substantial nigra at high levels (Fig. 6). In the thalamus, Ret, GFR $\alpha$-1, and GFR $\alpha-2$ were detected in the reticular and ventral medial nucleus (Fig. 6). In addition, coexpression of Ret, GFR $\alpha-1$, and/or GFR $\alpha-2$ was also observed in the hypothalamus, zona incerta, amygdala, and retina (Table 1). In contrast to Ret, GFR $\alpha-1$, and $\operatorname{GFR} \alpha-2$, GFR $\alpha$-3 was absent from the brain at both embryonic and postnatal stages (Figs. 1, 7; Table 1). These observations indicate that Ret is often accompanied by at least one of the three known $\alpha$-receptors.

\section{Unique expression of the GDNF family $\alpha$-receptors in projection targets of Ret-positive neurons in the nervous system}

In addition to the coexpression of one or more of the $\alpha$-receptors with Ret in a variety of different neuronal and non-neuronal tissues, various levels of GFR $\alpha-1$ and $\operatorname{GFR} \alpha-2$ expression were observed in many brain regions without significant Ret expression in the same location at the same developmental stages (see Figs. 7-10; Table 2). However, although Ret was not expressed in these same regions, it was transcribed invariably at high levels in the efferent neurons. Several efferent-target systems showed such differential expression. In the hippocamposeptal system, both GFR $\alpha-1$ and GFR $\alpha$-2 were transcribed at high levels in the lateral septum, the major subcortical target region of the hippocampal neurons in the CA regions (Figs. 7, 8). In contrast, little expression of these two receptors was observed in the medial septum, which sends projections to the hippocampus. Consistent with mediating hippocamposeptal interactions, Ret was clearly expressed in the hippocampal CA3 neurons (Fig. 8). Ret expression in the hippocampus appeared to start at late embryogenesis or the early postnatal period, because significant expression was observed at P7 but not at E18 (data not shown; Fig. 8). Furthermore, Ret expression was not accompanied by any $\alpha$-receptors in CA 3 at this stage, although they were expressed at low levels in the adult (data not shown) (also see Trupp et al., 1997).

In the trigeminal sensory system, trigeminal ganglia cells innervate the whiskerpads. High levels of GFR $\alpha-1$ and $\operatorname{GFR} \alpha-2$ were transcribed in the whiskerpads, whereas no significant Ret expression was observed in this area (Fig. 9). In contrast, high levels of Ret, along with all three known $\alpha$-receptors, are ex- 

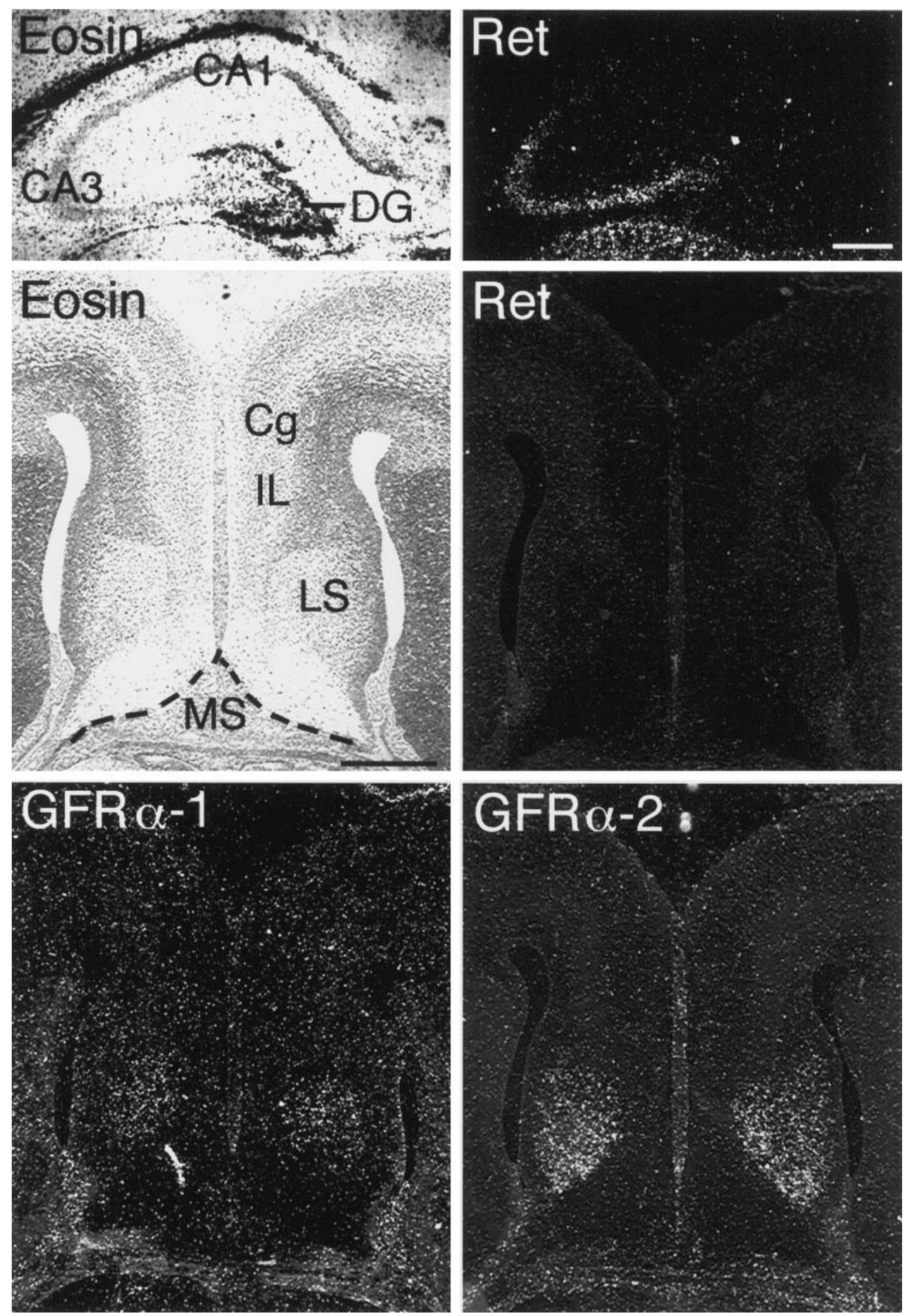

Figure 8. Expression of Ret, GFR $\alpha-1$, and GFR $\alpha-2$ in the rat hippocamposeptal system. Coronal sections through the P7 hippocampus (top two panels) and horizontal sections through the E18 septum (bottom four panels) were hybridized to antisense probes of Ret, GFR $\alpha-1$, and GFR $\alpha-2$. $C A 1, C A 3$, Cornu ammonis subregion 1 and $3 ; C g$, cingulate cortex; $D G$, dentate gyrus; $I L$, inferolimbic cortex; $L S$, lateral septum; $M S$, medial septum. Scale bars: hippocampus, $0.35 \mathrm{~mm}$; septum, $0.45 \mathrm{~mm}$.

pressed in the trigeminal ganglia (see previous section; Figs. 1, 7; Table 1). The third system that showed a clear target expression of the $\alpha$-receptors was the thalamocortical system. High levels of GFR $\alpha-2$ were transcribed specifically in layer 4 cortical neurons with no apparent Ret expression (Fig. 10; Table 2). Layer 4 cortical neurons are known to be innervated by neurons in the thalamus, where significant expression of Ret as well as GFR $\alpha-1$ and GFR $\alpha$-2 were detected (Fig. 6). In addition, high levels of GFR $\alpha-1$ and GFR $\alpha-2$ expression were also observed in the superior colliculus, whereas high levels of Ret, along with GFR $\alpha-1$, were expressed in the retina (Tables 1,2). These observations suggest that the interaction between GDNF family trophic factors, the $\alpha$-receptors, and Ret may mediate neuron-target interaction in many neural systems.

High levels of GFR $\alpha-1$ expression were also observed in the bed nucleus of the stria terminalis, the claustrum, the ventral pallidum, the dorsal endopiriform nucleus, and the habenular nucleus (Table 2). No or little Ret expression was observed in these areas. The significance of GFR $\alpha-1$ expression in these regions has not been fully investigated at the present time. 

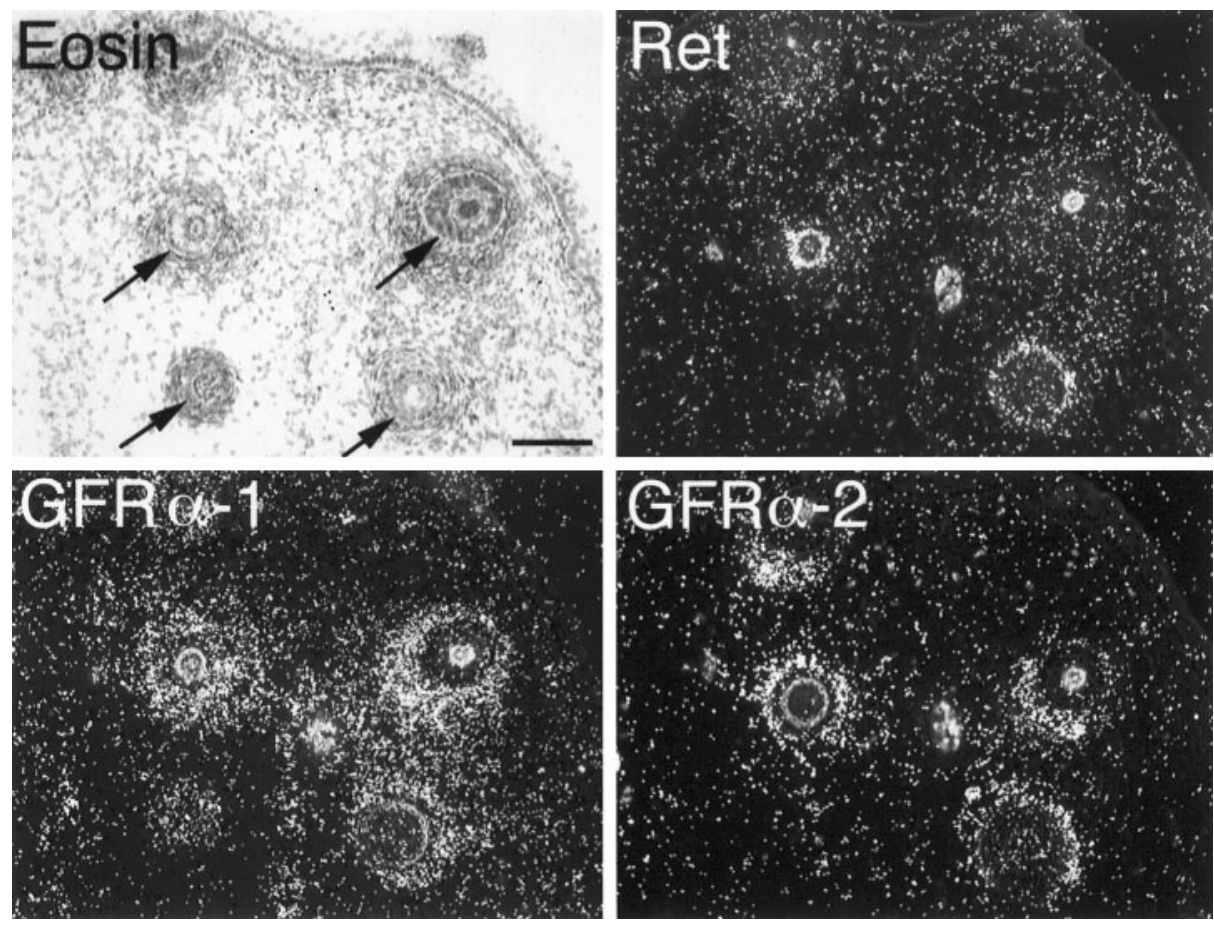

Figure 9. Expression of Ret, GFR $\alpha-1$, and GFR $\alpha-2$ in the whiskerpads. Serial frontal sections through the whiskerpads were hybridized to the antisense riboprobes of the three receptors, respectively. High levels of GFR $\alpha-1$ and GFR $\alpha-2$ were detected in the vibrissae (arrows), with no apparent Ret expression. The bright ring in the center of the vibrissae in the Ret dark-field picture is caused by eosin staining and is not a true hybridization signal. Scale bar, $10 \mu \mathrm{m}$.

\section{Activation of receptor tyrosine kinase Ret by GDNF and GFR $\alpha-1$ in trans}

Our in situ hybridization studies indicated that Ret may interact with the $\alpha$-receptors expressed either in the same cells (interaction in cis) or in target neurons (interaction in trans). It has been demonstrated previously that interaction in cis between Ret and GFR $\alpha-1$ or GFR $\alpha-2$ mediates the biological activity of the GDNF family ligands by coexpressing these receptors in the same cells (Jing et al., 1996, 1997; Treanor et al., 1996). To test the ability of GFR $\alpha-1$ to mediate Ret activation in trans, we provided GFR $\alpha-1 / F c$ either in soluble form or immobilized to protein A-Sepharose beads (Fig. 11A) to Ret-expressing Neuro-2a cells in the presence of GDNF. Both the soluble and the immobilized GDNF/GFR $\alpha$-1 complex strongly activated Ret tyrosine kinase (Fig. 11). In contrast, GFR $\alpha-1 / \mathrm{Fc}$ alone, whether soluble or immobilized, failed to activate Ret. GDNF alone also has very little activity in activating Ret, both in the presence and in the absence of protein A-Sepharose beads (Fig. 11B). These observations provide biochemical evidence that GFR $\alpha-1$ can indeed interact with Ret in trans in mediating GDNF function.

\section{DISCUSSION}

The molecular mechanism for GDNF and neurturin signaling has been well characterized in vitro. Both ligands exert their actions via a receptor complex composed of a ligand-binding receptor, either GFR $\alpha$-1 or GFR $\alpha$-2, and a signal-transducing component, the receptor protein tyrosine kinase Ret (Jing et al., 1996, 1997; Treanor et al., 1996; Baloh et al., 1997; Buj-Bello et al., 1997; Klein et al., 1997; Sanicola et al., 1997). Because both components of the receptor complex are required for GDNF and neurturin signaling, interaction of the GDNF family $\alpha$-receptors with Ret is essential for the function of these ligands. In this study we have compared the expression of Ret and three $\alpha$-receptors during rodent development to determine the mode of their interactions in vivo and provided in vitro evidence that GFR $\alpha-1$ can activate Ret in trans. These observations suggest that Ret and the $\alpha$-receptors may mediate not only the trophic effects of the GDNF family ligands on neurons by interacting in cis but also may regulate the functions of these ligands in neuron-target interactions by binding in trans.

\section{Coexpression of Ret and the $\alpha$-receptors: potential interactions in cis}

Comparison of the expression of Ret and $\alpha$-receptors showed that in most GDNF- and/or neurturin-responsive tissues, Ret is coexpressed with one or more of the $\alpha$-receptors. In agreement with previous knock-out studies indicating that GDNF and Ret are essential for embryonic development of kidney and intestine (Schuchardt et al., 1994; Moore et al., 1996; Pichel et al., 1996; Sanchez et al., 1996), we found both GFR $\alpha-1$ and Ret are highly expressed in these tissues at E18. Significant loss in trigeminal and spinal cord motoneurons, superior cervical ganglion neurons, and dorsal root ganglion neurons in Ret- and GDNF-null mice (Durbec et al., 1996a; Moore et al., 1996; Sanchez et al., 1996) is also well correlated with the coexpression of Ret and the $\alpha$-receptors in these neurons (Table 1). In superior cervical ganglia, where both GDNF and neurturin exhibit trophic activities, both GFR $\alpha-1$ and GFR $\alpha-2$ are coexpressed with Ret. Although its ligand is as yet unknown, GFR $\alpha-3$ is colocalized with Ret in all tissues where it is expressed, including the dorsal root and trigeminal ganglia (Figs. 1, 2, 4, 6, 7; Table 1). This suggests that Ret may also serve as the signaling receptor for the GFR $\alpha-3$ ligand.

Both Ret and one or more of the $\alpha$-receptors are also coexpressed in several tissues that are not known to be targets of either GDNF or neurturin. For example, high levels of Ret and GFR $\alpha-1$ transcripts were detected in the retina and thalamus (Table 1). The presence of Ret and the $\alpha$-receptors suggest that GDNF and related trophic factors may be required for the survival of neurons in these regions as well. The extensive coexpression suggests that the function of GDNF and neurturin may be mediated by interaction in cis between 

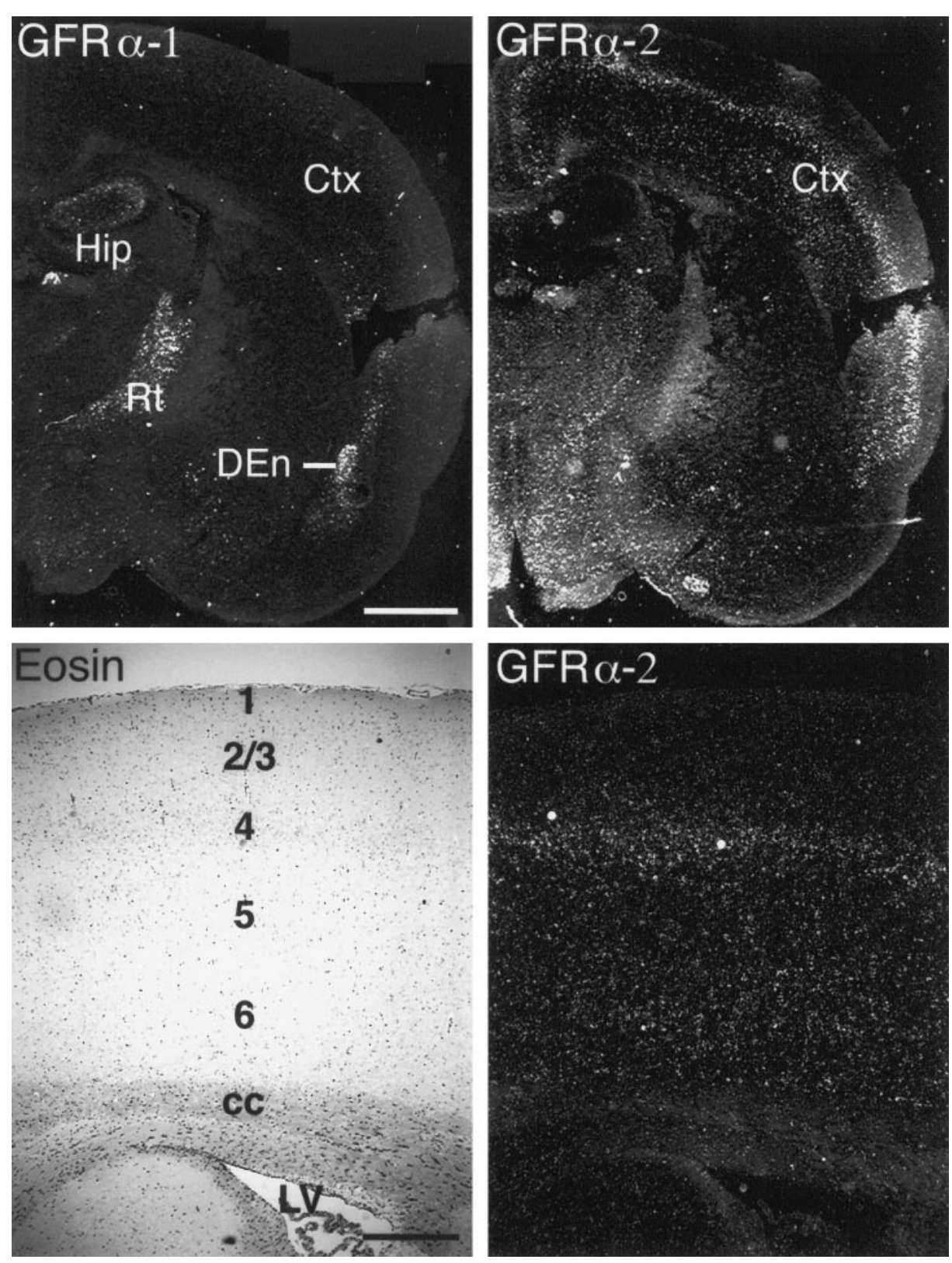

Figure 10. Expression of $\mathrm{GFR} \alpha-1$ and GFR $\alpha-2$ in the cortex. Coronal sections of the adult rat brain were hybridized to the antisense probes of GFR $\alpha-1$ and GFR $\alpha-2$. Sense probes of GFR $\alpha-1$ and GFR $\alpha-2$ showed no specific hybridization signals on adult brain sections (data not shown). Similar expression was observed in E18 and P7 rat brain. $c c$, Corpus callosum; $C t x$, cerebral cortex; $D E n$, dorsal endopiriform nucleus; Hip, hippocampus; $L V$, lateral ventricle; $R t$, reticular nucleus; $1-6$, cortical layers 1-6. Scale bars: top panels, $1.45 \mathrm{~mm}$; lower panels, $0.54 \mathrm{~mm}$.
Ret and the $\alpha$-receptors expressed in the same neurons. This is consistent with previous studies showing that coexpression of GFR $\alpha-1$ or GFR $\alpha$ - 2 with Ret in Neuro-2a cells is sufficient to mediate Ret activation by GDNF or neurturin (Jing et al., 1996, 1997; Treanor et al., 1996). Coexpression of Ret and the $\alpha$-receptors was observed in both pre- and postnatal tissues (Table 1), suggesting that in cis interaction may be important throughout rat development.

\section{Differential expression of the $\alpha$-receptors in the targets of Ret-positive neurons: potential interactions in trans}

In several tissues examined, the $\alpha$-receptors are also expressed at high levels without Ret. The most prominent examples are the lateral septum, whiskerpads, cortex, and superior colliculus. These regions transcribe high levels of GFR $\alpha-1$ and/or GFR $\alpha-2$ mRNAs but with no significant Ret expression. These observations in developing rats are similar to previously reported expression patterns of GFR $\alpha-1$ and Ret in the adult brain (Trupp et al.,
1997). The lack of Ret expression in these sites suggests that the $\alpha$-receptors may function by alternate mechanisms. It has been proposed that the $\alpha$-receptors may serve as GDNF or neurturin reservoirs to capture and present their ligands in trans to attract Ret-expressing axons, thus serving as target-derived chemotactic or trophic factors to guide incoming axons (Trupp et al., 1997). Consistent with this proposal, the $\alpha$-receptors are expressed in several regions that are targets of Ret-expressing neurons. These regions include the vibrissae, which is innervated by the trigeminal sensory neurons expressing high levels of Ret. Likewise, the high levels of GFR $\alpha-1$ and GFR $\alpha-2$ in the lateral septum may trap GDNF and neurturin and serve as chemotactic signals for incoming Ret-positive axons from neurons in hippocampal CA3 region. In addition, the presence of high GFR $\alpha$-2 expression in cortical layer 4, the specific target layer for thalamic neurons that transcribe high levels of Ret, provides further support to a possible role of GDNF family ligands and receptors in neuron-target interactions. It is intriguing to note that low levels of GFR $\alpha-2$ transcripts were observed in cortical layers 5 and 6 as well but that 


\begin{tabular}{lllll}
\hline \multicolumn{5}{l}{ Table 2. Distinct sites of expression of Ret and the $\boldsymbol{\alpha}$-receptors* } \\
Tissues & Ret & GFR $\alpha-1$ & GFR $\alpha-2$ & GFR $\alpha-3$ \\
\hline Hippocampus & & & & \\
$\quad$ Subiculum & - & +++ & - & - \\
CA1 & + & \pm & - & - \\
CA3 & ++ & - & - & - \\
Septum & & & & \\
Lateral & - & +++ & +++ & - \\
Medial & + & - & \pm & - \\
Cortex & & & & \\
Layer 4 & - & - & +++ & - \\
Layers 5 and 6 & - & - & + & - \\
Superior colliculus & - & ++ & +++ & - \\
BST** & - & ++ & - & - \\
Claustrum & - & +++ & - & - \\
Ventral pallidum & - & +++ & - & - \\
Dorsal endopiriform nucleus & \pm & +++ & - & - \\
Habenular nucleus & \pm & +++ & ++ & - \\
Whiskerpad & - & +++ & + & - \\
\hline
\end{tabular}

*Data from P7 rats. ${ }^{* *}$ Bed nucleus of the stria terminalis.,,,++++++ \pm , and indicate strong, moderate, weak, very weak, and no hybridization signals.

no expression was observed in layer $2 / 3$. These observations suggest that incoming thalamic axons may be promoted to grow into the cortex across layers 5 and 6 to end in layer 4, where the highest level of GFR $\alpha-2$ expression has been found.

Although more detailed analyses are needed to examine the precise temporal regulation of expression, the presence of both Ret and the $\alpha$-receptor transcripts in trigeminal, thalamocortical, and the retinotectal systems at E18, a time when active ingrowth of axons into their targets occurs, is consistent with roles in neuron-target interactions. The ingrowth of the hippocampal axons to the lateral septum occurs from E21 to P14 in the rat (Linke et al., 1995). Thus the delayed expression of Ret in the hippocampal CA regions also correlates with the timing of axonal growth into the septal target. Taken together, the complementary expression of Ret and the $\alpha$-receptors in projecting and target fields supports the view that the signaling and the ligand-binding receptors may interact in trans to regulate neuron-target interactions.

\section{Activation of Ret tyrosine kinase in trans by GDNF/ GFR $\alpha$-1 complex in vitro}

A critical prediction of the proposal that Ret may interact with the $\alpha$-receptors in trans is that the $\alpha$-receptors provided from outside the Ret-expressing cells should be able to mediate Ret activation by GDNF or neurturin. To test this prediction, we examined the ability of both soluble and protein A-Sepharose bead-immobilized GDNF/GFR $\alpha-1 / \mathrm{Fc}$ complex to activate Ret tyrosine kinase expressed on the surface of Neuro-2a cells. Both the soluble and the immobilized complex greatly stimulated Ret kinase activity, even though it was provided in trans. Our observations confirm and extend previous studies that showed that GDNF and neurturin activate Ret kinase in the presence of soluble GFR $\alpha-1$ and GFR $\alpha$-2 (Jing et al., 1996; Treanor et al., 1996; Klein et al., 1997), providing further biochemical support for a functional interaction in trans.

\section{Multiple mechanisms of regulation of nervous system development by the GDNF family trophic factors}

Target-derived neurotrophic factors play key roles in maintaining the survival and integrity of the efferent neurons and pathways in
Figure 11. Activation of Ret tyrosine kinase in trans by soluble or immobilized GDNF/ GFR $\alpha$ - 1 complex. $A$, Stable association of GDNF/GFR $\alpha-1 /$ Fc complex with protein A-Sepharose beads. The GDNF/GFR $\alpha-1 / \mathrm{Fc}$ complex was immobilized on protein A-Sepharose beads by mixing GDNF (50 nM) with the conditioned medium of GFR $\alpha$ 1-producing 293T cells and with protein A-Sepharose beads as described in Materials and Methods. To examine whether there was dissociation of the GDNF/GFR $\alpha-1 / \mathrm{Fc}$ complex from the protein A beads, we resuspended aliquots of the protein A complex in binding buffer and incubated these at $37^{\circ} \mathrm{C}$ for various times as indicated. The supernatants were then analyzed with Western blot for the presence of dissociated GDNF/ GFR $\alpha-1 /$ Fc complex as described in Materials and Methods. An aliquot of the conditioned medium containing an approximately equivalent amount of GFR $\alpha-1 / \mathrm{Fc}$ was included in the blot for comparison $(G F R \alpha$ $1 / F($ lane $)$. No dissociated $\mathrm{GFR} \alpha-1 / \mathrm{Fc}$ was detected (0-10 min lanes). $B$, Activation of Ret receptor tyrosine kinase by soluble or protein A-immobilized GDNF/GFR $\alpha-1 / \mathrm{Fc}$ complex. Soluble or protein A-immobilized GDNF/GFR $\alpha-1 /$ Fc complex was added to Neuro-2a cells that express Ret and incubated for $5 \mathrm{~min}$. The treated cells were then analyzed for Ret activation as described in Materials and Methods.

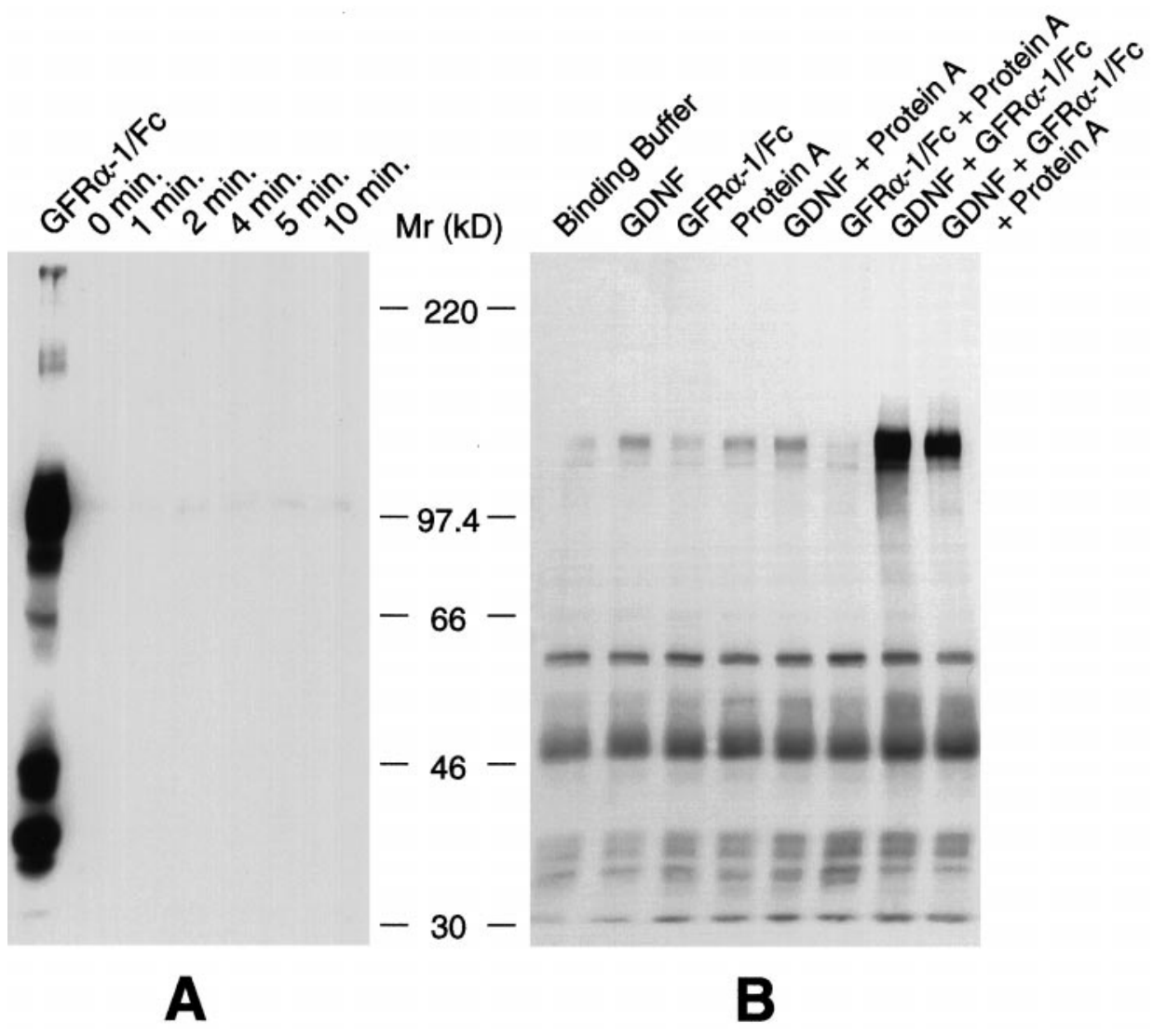


the nervous system. The ability of the GDNF family ligands to maintain neuronal survival suggests that these molecules may serve as target-derived factors to regulate the survival of projecting neurons and to provide attractive guidance to incoming Retpositive axons.

The expression patterns revealed here suggest that there are many mechanisms to regulate neuronal survival and neurontarget interaction by the GDNF family trophic factors and their receptors. For neurons coexpressing Ret and one of the $\alpha$-receptors, expression of GDNF or related ligands in the target tissues would be sufficient to generate target-derived attractive guidance cues or survival signals. It is important to note that these target-derived factors may serve as positive guidance cues or survival signals or both. Evidence that GDNF and neurturin are transcribed in the striatum, the projection target of the substantia nigra neurons that express both Ret and GFR $\alpha-1$, supports this proposal (Schaar et al., 1993; Stromberg et al., 1993; Springer et al., 1994; Suvanto et al., 1996; Trupp et al., 1997; Widenfalk et al., 1997). An alternative mechanism is to express $\alpha$-receptors to serve as traps for GDNF and related ligands in the target tissues. These ligand and GFR complexes may then interact in trans with Ret expressed on incoming axons. In this study, we present evidence that the $\alpha$-receptors are indeed expressed in targets of Ret-expressing neurons in several systems including the trigeminal, hippocamposeptal, thalamocortical, and the retinotectal pathways. We further demonstrated that in vitro Ret can be activated efficiently in trans by the GDNF/GFR $\alpha-1$ complex, supporting a key role for the $\alpha$-receptors in target regulations of the projecting neurons.

Because GDNF and related trophic factors are diffusible, it may be difficult to restrict these factors to particular regions of the brain. Furthermore, peripheral sources such as the kidney may provide high levels of GDNF or neurturin throughout the brain during development before the blood-brain barrier has been established. Therefore the highly localized expression of the $\alpha$-receptors may thus provide a key mechanism for the functional specificity of GDNF and related trophic factors. Taken together, the actions of the GDNF family ligands in neuronal survival and/or neuron-target interactions are likely to be regulated by multiple mechanisms.

\section{REFERENCES}

Baloh R, Tansey M, Golden J, Creedon D, Heuckeroth R, Keck C, Zimonjic D, Popescu N, Johnson E, Milbrandt J (1997) TrnR2, a novel receptor that mediates neurturin and GDNF signaling through Ret. Neuron 18:793-802.

Beck K, Valverde J, Alexi T, Poulsen K, Moffat B, Vandlen R, Rosenthal A, Hefti F (1995) Mesencephalic dopaminergic neurons protected by GDNF from axotomy-induced degeneration in the adult brain. Nature 373:339-341.

Buj-Bello A, Buchman VL, Horton A, Rosenthal A, Davies AM (1995) GDNF is an age-specific survival factor for sensory and autonomic neurons. Neuron 15:821-828.

Buj-Bello A, Adu J, Pinon LG, Horton A, Thompson J, Rosenthal A, Chinchetru M, Buchman VL, Davies AM (1997) Neurturin responsiveness requires a GPI-linked receptor and the Ret receptor tyrosine kinase. Nature 387:721-724.

Durbec PL, Larsson-Blomberg LB, Schuchardt A, Costantini F, Pachnis V (1996a) Common origin and developmental dependence on c-ret of subsets of enteric and sympathetic neuroblasts. Development 122:349-358

Durbec P, Marcos-Gutierrez CV, Kilkenny C, Grigoriou M, Suvanto P, Wartiovaara K, Smith D, Ponder B, Costantini F, Saarma M, Sariola H, Pachnis V (1996b) Glial cell line-derived neurotrophic factor signalling through the Ret receptor tyrosine kinase. Nature 381:789-792.
Ebendal T, Tomac A, Hoffer BJ, Olson L (1995) Glial cell line-derived neurotrophic factor stimulates fiber formation and survival in cultured neurons from peripheral autonomic ganglia. J Neurosci Res 40:276-284.

Edery P, Lyonnet S, Mulligan L, Pelet A, Dow E, Abel L, Holder S, Nihoul-Fekete C, Poder B, Munnich A (1994) Mutations of the ret proto-oncogene in Hirschsprung's disease. Nature 367:378-380.

Henderson CE, Phillips HS, Pollock RA, Davies AM, Lemeulle C, Armanini M, Simpson LC, Moffet B, Vandlen RA, Koliatsos VE, Rosenthal A (1994) GDNF: a potent survival factor for motoneurons present in peripheral nerve and muscle. Science 266:1062-1064.

Iwamoto T, Taniguchi M, Asai N, Ohkusu K, Nakashima I, Takahashi M (1993) cDNA cloning of mouse ret proto-oncogene and its sequence similarity to the cadherin superfamily. Oncogene 8:1087-1091.

Jing SQ, Wen DZ, Yu YB, Holst PL, Luo Y, Fang M, Tamir R, Antonio L, Hu Z, Cupples R, Louis JC, Hu S, Altrock BW, Fox GM (1996) GDNF-induced activation of the ret protein tyrosine kinase is mediated by GDNFR alpha, a novel receptor for GDNF. Cell 85:1113-1124.

Jing S, Yu Y, Hu Z, Fang M, Hu Z, Holst PL, Boone T, Delaney J, Schultz H, Zhou R, Fox GM (1997) GFR $\alpha-2$ and GFR $\alpha-3$ are two new receptors for ligands of the GDNF family. J Biol Chem 52:33111-33117.

Klein RD, Sherman D, Ho W-H, Stone D, Bennett GL, Moffat B, Vandlen R, Simmons L, Gu Q, Hongo J-A, Devaux B, Poulsen K, Armanini M, Nozaki C, Asai N, Goddard A, Phillips H, Henderson CE, Takahashi M, Rosenthal A (1997) A GPI-linked protein that interacts with Ret to form a candidate neurturin receptor. Nature 387:717-721.

Kotzbauer P, Lampe P, Heuckeroth R, Golden J, Creedon D, Johnson E, Mibrandt J (1996) Neurturin, a relative of glial-cell-line-derived neurotrophic factor. Nature 384:467-470.

Li LX, Wu WT, Lin LFH, Lei M, Oppenheim RW, Houenou LJ (1995) Rescue of adult mouse motoneurons from injury-induced cell death by glial cell line-derived neurotrophic factor. Proc Natl Acad Sci USA 92:9771-9775.

Lin L-FH, Doherty D, Lile J, Bektesh S, Collins F (1993) GDNF: a glial cell line-derived neurotrophic factor for midbrain dopaminergic neurons. Science 260:1130-1132.

Linke R, Pabst T, Frotscher M (1995) Development of the hippocamposeptal projection in the rat. J Comp Neurol 351:602-616.

Moore MW, Klein RD, Farinas I, Sauer H, Armanini M, Phillips H, Reichardt LF, Ryan AM, Carvermoore K, Rosenthal A (1996) Renal and neuronal abnormalities in mice lacking GDNF. Nature 382:76-79.

Mount HTJ, Dean DO, Alberch J, Dreyfus CF, Black IB (1995) Glial cell line-derived neurotrophic factor promotes the survival and morphologic differentiation of Purkinje cells. Proc Natl Acad Sci USA 92:9092-9096.

Oppenheim R, Houenou L, Johnson J, Lin L-F, Li L, Lo A, Newsome A, Prevette D, Wang S (1995) Developing motor neurons rescued from programmed cell death by GDNF. Nature 373:344-346.

Pichel JG, Shen LY, Sheng HZ, Granholm AC, Drago J, Grinberg A, Lee EJ, Huang SP, Saarma M, Hoffer BJ, Sariola H, Westphal H (1996) Defects in enteric innervation and kidney development in mice lacking GDNF. Nature 382:73-76.

Romeo G, Patrizia R, Luo Y, Barone V, Seri M, Ceccherini I, Pasini B, Bocciards R, Lerone M, Kaariainen H, Maartucciello G (1994) Point mutations affecting the tyrosine kinase domain of the ret protooncogene in Hirschsprung's disease. Nature 367:377-378.

Sanchez MP, Silossantiago I, Frisen J, He B, Lira SA, Barbacid M (1996) Renal agenesis and the absence of enteric neurons in mice lacking GDNF. Nature 382:70-73.

Sanicola M, Hession C, Worley D, Carmillo P, Ehrenfels C, Walus L, Robinson S, Jaworski G, Wei H, Tizard R, Whitty A, Pepinsky RB, Cate RL (1997) Glial cell line-derived neurotrophic factor-dependent Ret activation can be mediated by two different cell-surface accessory proteins. Proc Natl Acad Sci USA 94:6238-6243.

Schaar DG, Sieber B-A, Dreyfus CF, Black IB (1993) Regional and cell-specific expression of GDNF in rat brain. Exp Neurol 124:368-371.

Schuchardt A, D’Agati V, Larsson BL, Costantini F, Pachnis V (1994) Defects in the kidney and enteric nervous system of mice lacking the tyrosine kinase receptor Ret. Nature 367:380-383.

Springer JE, Mu X, Bergmann LW, Trojanowski JQ (1994) Expression of GDNF mRNA in rat and human nervous tissue. Exp Neurol 127:167-170.

Stromberg I, Bjorklund L, Johansson M, Tomac A, Collins F, Olson L, Hoffer B, Humpel C (1993) Glial cell line-derived neurotrophic factor 
is expressed in the developing but not adult striatum and stimulates developing dopamine neurons in vivo. Exp Neurol 124:401-412.

Suvanto P, Hiltunen JO, Arumae U, Moshnyakov M, Sariola H, Sainio K, Saarma M (1996) Localization of glial cell line-derived neurotrophic factor (GDNF) mRNA in embryonic rat by in situ hybridization. Eur J Neurosci 8:816-822.

Tomac A, Lindqvist E, Lin L-F, Ögren S, Young D, Hoffer B, Olson L (1995) Protection and repair of the nigrostriatal dopaminergic system by GDNF in vivo. Nature 373:335-339.

Treanor J, Goodman L, Desauvage F, Stone DM, Poulsen KT, Beck CD, Gray C, Armanini MP, Pollock RA, Hefti F, Phillips HS, Goddard A, Moore MW, Bujbello A, Davies AM, Asai N, Takahashi M, Vandlen R, Henderson CE, Rosenthal A (1996) Characterization of a multicomponent receptor for GDNF. Nature 382:80-83.

Trupp M, Rydén M, Jörnvall H, Timmusk T, Funakoshi H, Arenas E, Ibáñez CF (1995) Peripheral expression and biological activities of GDNF, a new neurotrophic factor for avian and mammalian peripheral neurons. J Cell Biol 130:137-148.

Trupp M, Arenas E, Fainzilber M, Nilsson A-S, Sieber BA, Grigoriou M, Kilkenny C, Salazar-Grueso E, Pachnis V, Arumäe U, Sariola H,
Saarma M, Ibáñez CF (1996) Functional receptor for glial cell linederived neurotrophic factor encoded by the c-ret proto-oncogene product. Nature 381:785-789.

Trupp M, Belluardo N, Funakoshi H, Ibáñez CF (1997) Complementary and overlapping expression of glial cell line-derived neurotrophic factor (GDNF), c-ret proto-oncogene, and GDNF receptor- $\alpha$ indicates multiple mechanisms of trophic actions in the adult rat CNS. J Neurosci 17:3554-3567.

Widenfalk J, Nosrat C, Tomac A, Westphal H, Hoffer B, Olson L (1997) Neurturin and glial cell line-derived neurotrophic factor receptor- $\beta$ (GDNFR- $\beta$ ), novel proteins related to GDNF and GDNFR- $\alpha$ with specific cellular patterns of expression suggesting roles in the developing and adult nervous system and in peripheral organs. J Neurosci 17:8506-8519.

Yan Q, Matheson C, Lopez O (1995) In vivo neurotrophic effects of GDNF on neonatal and adult facial motor neurons. Nature 373:341-344

Zhang J, Pimenta A, Levitt P, Zhou R (1997) Dynamic expression suggests multiple roles of the eph family receptor brain-specific kinase (Bsk) during mouse neurogenesis. Mol Brain Res 47:202-214. 